\title{
THE SMALL BOWEL FLORA IN INDIVIDUALS WITH CECOILEAL REFLUX
}

\author{
Wellington Monteiro MACHADO ${ }^{1}$, José Ricardo Arruda MIRANDA², \\ José MORCELI ${ }^{1}$ and Carlos Roberto PADOVANI ${ }^{2}$
}

\begin{abstract}
Background - The observation of cecoileal reflux to barium enema is not rare; however, its causes and consequences have not been widely investigated. Considering that ileocecal junction exerts a function as barrier to invasion of bacteria from colon to small bowel, it seems interesting to study the intestinal microflora in subjects carrying cecoileal reflux. Aims - This study aims at evaluating the ileal flora in individuals with cecoileal reflux. Methods - A group of 36 subjects comprising 30 females and 6 males with a mean age of 54 years was assessed. Twenty-five individuals with cecoileal reflux and 11 without cecoileal reflux were submitted to small intestine contamination evaluation through the breath test with lactulose- $\mathrm{H}_{2}$ and measurement of the orocecal transit time by means of alternate current biosusceptometry. Small intestine bacterial overgrowth was characterized by orocecal transit time- $\mathrm{H}_{2}$ shortening. Results - Comparison of basal $\mathrm{H}_{2}$, orocecal transit time- $\mathrm{H}_{2}$ and orocecal transit time-alternate current biosusceptometry measurements did not statistically differ between the groups with and without cecoileal reflux. Orocecal transit time- $\mathrm{H}_{2}$ was significantly smaller than orocecal transit time-alternate current biosusceptometry, particularly in individuals with cecoileal reflux. A significant correlation between the two methods was observed only in relation to control, not existing in relation to cecoileal reflux group. Conclusions - Smaller orocecal transit time- $\mathrm{H}_{2}$ and the loss of correlation with orocecal transit time-alternate current biosusceptometry observed in the individuals with cecoileal reflux suggest a differentiated behavior for such group relative to control, which could be associated with small intestine bacterial overgrowth.
\end{abstract}

HEADINGS - Cecoileal reflux. Ileocecal valve. Small bowel contamination. Small bowel bacterial overgrowth. Ileocecal junction.

\section{INTRODUCTION}

The ileocecal junction (ICJ) is alternatively defined as a valve, sphincter or both ${ }^{(2,3,42,54)}$. The difficulty in its accurate characterization is partly due to its location, the access to which is troublesome, consequently hindering more frequent and prolonged studies. However, most authors acknowledge it as a differentiated area of the digestive tract with specific characteristics and specialized motor behavior ${ }^{(5,42,54)}$.

Two major functions have been attributed to the ICJ: control of bowel flow towards the colon and prevention of cecal content reflux into the terminal ileum ${ }^{(5,10,20,22 \text {, }}$ $25,35,37$. To perform such function, ICJ seems to depend not only on its peculiar neuromuscular structure of sphincteric characteristics ${ }^{(5,30,42)}$, but also on the anatomical arrangement of its components, which form a type of restraint point resulting from the angulation formed by the junction of the terminal ileum and the cecum ${ }^{23,24,}$ 42). Abnormality in these structures may favor motility disorders or contamination of the small intestine by the rich anaerobic flora from the cecum. Experimental and clinical studies have confirmed these possibilities by showing alterations in bowel transit time ${ }^{(12,22,50,52)}$ and bacterial invasion of the small intestine ${ }^{(13,20,36)}$ in conditions where ICJ has been somehow damaged.
A relatively common observation is the occurrence of cecoileal reflux (CIR) in barium enema ${ }^{(8,28,33)}$. These are refluxes of varying intensity that oscillate from small to large which can fill long ileal segments. What does this finding mean? Would it simply be a variant of normality and, therefore, bring no consequences, or, on the contrary, would it hide still undescribed meanings? The hypothesis of CIR innocuousness seems, however, rather implausible as it would differ from the behavior of refluxes in other topographies of the digestive system, where they exhibit a high complication potential, generating such frequent and repercussive diseases as the gastroesophageal reflux disease (GERD) $)^{(11,16)}$.

What is actually observed is that, perhaps due to the difficulties in approaching ICJ, the most frequently adopted conduct has been that of disregarding the importance of CIR and considering it as an irrelevant and common finding with no specific diagnostic meaning. But would that be it? After all, more than $75 \%$ of the individuals submitted to barium enema do not exhibit significant reflux $^{(28)}$, and some studies report the expressive force of resistance to reflux presented by $\operatorname{ICJ}^{(23,50)}$. Contrarily, would individuals with reflux not present intrinsic restraint mechanism disorders that could be associated with ileal emptying alteration, thus generating favorable conditions for bacterial contamination of the small intestine?

School of Medicine, Paulista State University - UNESP; ${ }^{2}$ Biosciences Institute - UNESP, Botucatu, SP, Brazil.

Correspondence: Dr. Wellington M. Machado - Departamento de Clínica Médica - Faculdade de Medicina de Botucatu - 18618-000 - Botucatu, SP, Brazil.

E-mail: wmachado@fmb.unesp.br 
Unaware of investigations which have approached such question, we decided to conduct this study with the purpose to evaluate whether individuals with CIR would present small intestine bacterial overgrowth (SIBO).

\section{METHODS}

\section{Subjects}

A group of 36 individuals comprising 30 females and 6 males with a mean age of 52.9 years (range $20-75$ years) was examined. Such individuals were distributed into three groups: a control group consisting of 11 subjects without CIR (group A), 9 females and 2 males at a mean age of 51.2 years (range 35-66 years), a second group consisting of 14 individuals with moderate CIR (group M), 10 females and 4 males at a mean age of 55.3 years (range 36-71 years), and a third group represented by 11 subjects with severe CIR (group S), consisting of females at a mean age of 54.6 years (range 29-75 years). The characterization of each group was based on the results of previously performed barium enema, according to which the control group included only individuals with absence of reflux; the moderate group comprised those with reflux penetrating up to $20 \mathrm{~cm}$ into the ileum and remaining there during radiological examination; and the severe group consisted of individuals with reflux whose penetration exceeded $20 \mathrm{~cm}$ into the distal ileum and remained there during examination (Figure 1). The

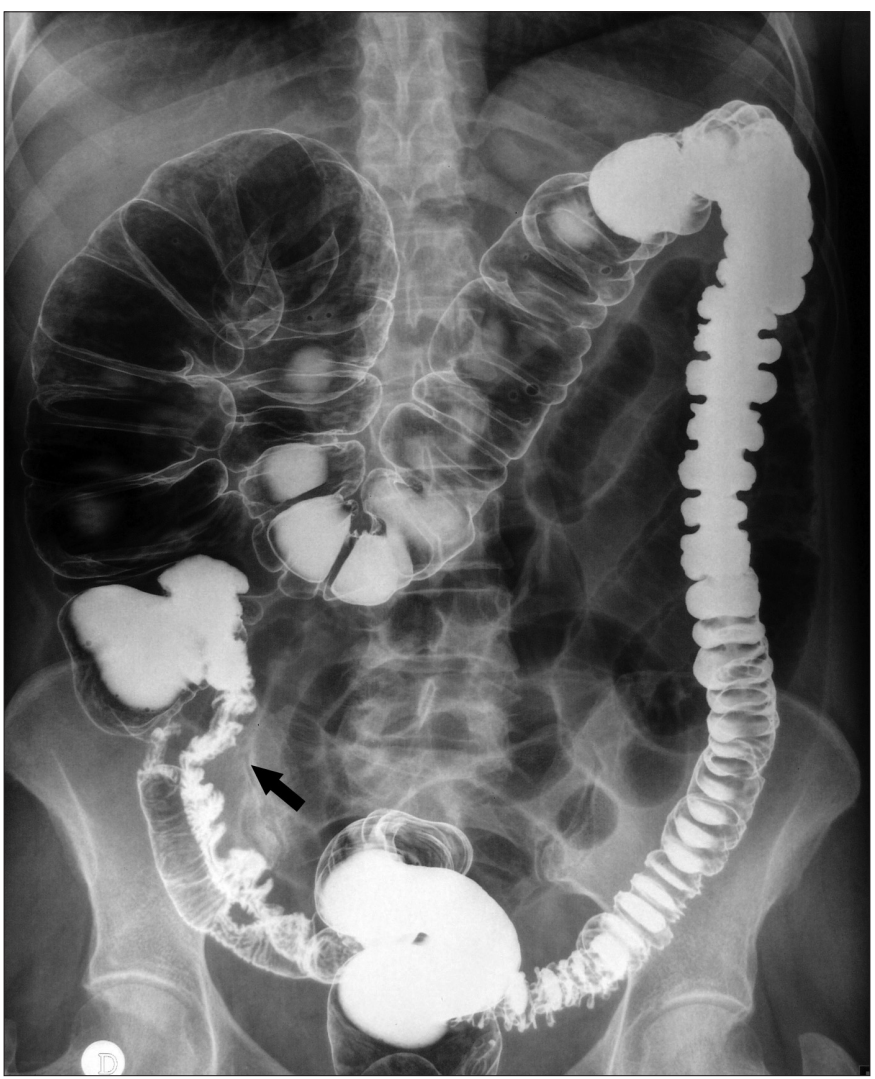

FIGURE 1. Barium enema showing cecoileal reflux (see arrow) definitions for characterization of moderate and severe reflux were arbitrary and operational, based on a study previously published by $\mathrm{us}^{(28)}$. All individuals with disorders predisposing to alteration of the small intestine transit, alteration of the ileocecal valve and to flora modification were excluded from the investigation.

The study was approved by the Research Ethics Committee of the Botucatu School of Medicine, and the participants signed a informed consent form for inclusion in the project.

\section{Methods}

\section{Small bowel flora assessment}

Such assessment was performed by means of a hydrogen $\left(\mathrm{H}_{2}\right)$ breath test using lactulose as substrate ${ }^{(27,44,48)}$. Expiration-end air samples were collected into three-way $50 \mathrm{dL}$ polypropylene syringes by the Haldane-Priestley modified method for alveolar air collection ${ }^{(31,32,51)}$ using a polyvinyl tube of $1.70 \mathrm{~m}$ in length and $13 \mathrm{~mm}$ in internal diameter. Both the tube and the syringes were previously tested as for gas collection, transportation and storage safety.

The samples of exhaled air were analyzed for $\mathrm{H}_{2}$ concentration by a thermal conductivity gas chromatograph, model CG20 ("Instrumentos Científicos CG Ltda."), fitted with a column measuring $1.83 \mathrm{~m}$ in length and $6.3 \mathrm{~mm}$ in internal diameter packed with a molecular sieve with a granulometric mesh of $50 \AA$ 60/80 (Field Instruments Co Ltd, Surrey, England), operated at $50^{\circ} \mathrm{C}$ with ultra-pure nitrogen $\left(\mathrm{N}_{2}\right)$ as carrier gas at a flow of $60 \mathrm{~mL} / \mathrm{minute}$. Chromatograms were obtained by a pen recorder on millimeter paper at a speed of $0.25 \mathrm{~cm} /$ minute. Chromatograms were quantified by the comparison between the obtained $\mathrm{H}_{2}$ peak height and that of the standard gas sample containing $100 \mathrm{ppm}$ of $\mathrm{H}_{2}$ in ultra-pure $\mathrm{N}_{2}{ }^{(29,32,51)}$.

\section{Determination of orocecal transit time by alternate current biosusceptometry}

The use of alternate current biosusceptometry $(\mathrm{ACB})^{(1,34,40)}$ aimed at obtaining a measurement of the orocecal transit time (OCTT) regardless of bacterial influence, which is useful in a situation such as that presently studied, where the analyzed groups could have distinct intestinal flora and, therefore, generate OCTT with heterogeneous values, if measured by the exhaled $\mathrm{H}_{2}$ test. It is an apparently innocuous method with consistent results in determining OCTT in individuals ${ }^{(40)}$. During its performance, a magnetized substance, manganese ferrite $\left(\mathrm{MnFe}_{2} \mathrm{O}_{4}\right)$, is orally administered. Following ingestion, its course can be tracked in the digestive tube by means of a magnetic signal movable external sensor denominated AC biosusceptometer ${ }^{(1)}$, positioned on the abdominal wall. OCTT is defined as the time interval between the ingestion of ferrite powder and the moment when it reaches the region previously established as corresponding to the ileocecal transition. In this study, such region projected into the right lower quadrant of the abdomen, approximately $2 \mathrm{~cm}$ below McBurney's point. 
The exhaled $\mathrm{H}_{2}$ tests and $\mathrm{ACB}$ were simultaneously performed and observed the following routine:

a) on the previous day to the exam: diet poor in carbohydrate of difficult absorption. Meals containing preferably rice, meat and eggs were recommended;

b) 12-hour nightly fast;

c) prior to reporting to the laboratory: rigorous oral hygiene, suspension of cigarette use and exhaustive physical activity;

d) collection of two expiration-end basal air samples;

e) ingestion of the testing mixture composed of $12 \mathrm{~g}$ of lactulose dissolved in $100 \mathrm{~mL}$ of water added to approximately $50 \mathrm{~mL}$ of a chocolate liquid (Danette ${ }^{\circledR}$ ) containing $4 \mathrm{~g}$ of ferrite powder. When the meal was completed, expiration air samples were collected every 10 min during 3 consecutive hours in order to determine $\mathrm{H}_{2}$ concentration. The magnetic signal was tracked until it reached the region corresponding to McBurney's point, and the time consumed in the course was calculated.

In the study on the contamination of the small intestine by means of the breath test, different criteria from those traditionally used for SIBO characterization were adopted ${ }^{(21,44,48)}$. The reasons for such choice were based on the fact that, differently from habitual situations in which contamination is usually segmental and localized in proximal intestinal portions, in the condition herein explored, it presumably originates distally, beginning at the terminal ileum from which it would extend retrogradely. Depending on the height reached by reflux, intestinal colonization would be established in higher ileal regions, resulting in earlier initial $\mathrm{H}_{2}$ peaks in individuals exhibiting CIR than in those who do not, since the contact of lactulose with fermenting bacteria would be anticipated in the former. Consequently, OCTT measured by $\mathrm{H}_{2}$ would be shortened in the presence of ascendant ileal contamination. Based on this assumption, the OCTT- $\mathrm{H}_{2}$ shortening criterion was used in the diagnosis of altered flora in substitution for the conventional method, which is based on the occurrence of a double peak of exhaled $\mathrm{H}_{2}{ }^{(21,48)}$. OCTT- $\mathrm{H}_{2}$ was defined as the time elapsed between lactulose ingestion and the increase of exhaled $\mathrm{H}_{2}$ at 3, 5 or $10 \mathrm{ppm}$ above the basal values. The justification for the use of three cut off value alternatives in the OCTT- $\mathrm{H}_{2}$ definition was to sensitize the diagnostic level of the breath test ${ }^{(4,15,17,47,53)}$.

\section{Statistical analysis}

The comparison of basal $\mathrm{H}_{2}, \mathrm{OCTT}_{-} \mathrm{H}_{2}$ and OCTT-ACB between the control and CIR groups was performed by the non-parametric test of Kruskal-Wallis and complemented by the respective test of multiple comparisons. In order to study the association between the two OCTT measurement methods, Spearman's correlation coefficient was utilized. The level of significance adopted in the study was of $5 \%{ }^{(39)}$.

\section{RESULTS}

The result of basal $\mathrm{H}_{2}$ and OCTT values for participants in the groups $\mathrm{A}, \mathrm{M}, \mathrm{S}$, as measured by lactulose- $\mathrm{H}_{2}$ and $\mathrm{ACB}$, are shown in Tables 1, 2 and 3.
TABLE 1. Basal $\mathrm{H}_{2}, \mathrm{OCTT}^{\mathrm{O}} \mathrm{H}_{2}$ and OCTT-ACB in individuals without CIR

\begin{tabular}{cccccc}
\hline $\begin{array}{c}\text { Fasting } \mathrm{H}_{2} \\
(\mathrm{ppm})\end{array}$ & $\begin{array}{c}\text { OCTT- } \mathrm{H}_{2} / 3 \\
(\mathrm{~min})\end{array}$ & $\begin{array}{c}\mathrm{OCTT}^{2} \mathrm{H}_{2} / 5 \\
(\mathrm{~min})\end{array}$ & $\begin{array}{c}\text { OCTT- } \mathrm{H}_{2} / 10 \\
(\mathrm{~min})\end{array}$ & $\begin{array}{c}\text { OCTT-ACB } \\
(\mathrm{min})\end{array}$ \\
\hline 3.51 & 120 & 130 & 140 & 100 \\
& 5.46 & 20 & 20 & 40 & 60 \\
& 6.1 & 40 & 50 & 50 & 50 \\
& 0.97 & 110 & 120 & 150 & 110 \\
& 1.3 & 90 & 90 & 100 & 100 \\
& 1.17 & 20 & 20 & 50 & 30 \\
& 1.22 & 30 & 40 & 60 & 80 \\
& 15.92 & 70 & 70 & 90 & 140 \\
& 7 & 60 & 60 & 80 & 80 \\
Median \pm Total & 3.9 & 70 & 70 & 100 & 120 \\
semiamplitude & $3.51 \pm 7.48$ & $60.00 \pm 50.00$ & $70.00 \pm 55.00$ & $90 \pm 55.00$ & $100 \pm 55.00$ \\
\hline
\end{tabular}

TABLE 2. Basal $\mathrm{H}_{2}$, OCTT- $\mathrm{H}_{2}$ and OCTT-ACB of individuals with moderate CIR

\begin{tabular}{ccccc}
\hline $\begin{array}{c}\text { Fasting } \mathrm{H}_{2} \\
(\mathrm{ppm})\end{array}$ & $\begin{array}{c}\mathrm{OCTT}_{2} \mathrm{H}_{2} / 3 \\
(\mathrm{~min})\end{array}$ & $\begin{array}{c}\mathrm{OCTT} \mathrm{H}_{2} / 5 \\
(\mathrm{~min})\end{array}$ & $\begin{array}{c}\mathrm{OCTT}_{2} / 10 \\
(\mathrm{~min})\end{array}$ & $\begin{array}{c}\text { OCTT-ACB } \\
(\mathrm{min})\end{array}$ \\
\hline 1.2 & 40 & 50 & 60 & 120 \\
3 & 70 & 70 & 80 & 80 \\
1.02 & 50 & 50 & 50 & 110 \\
3 & 70 & 50 & 90 & 110 \\
4.8 & 20 & 80 & 90 & 80 \\
33.16 & 80 & 20 & 20 & 110 \\
13.7 & 110 & 110 & 130 & 100 \\
4.1 & 110 & 120 & 130 & 110 \\
2 & 50 & 60 & 70 & 60 \\
5.85 & 120 & 120 & 130 & 130 \\
9 & 30 & 30 & 50 & 110 \\
1.02 & 40 & 70 & 70 & 140 \\
1.02 & 30 & 30 & 30 & 50
\end{tabular}

Median \pm Total

$\begin{array}{llllll}\text { semiamplitude } & 3.00 \pm 16.58 & 50.00 \pm 50.00 & 65.00 \pm 50.00 & 75.00 \pm 55.00 & 110.00 \pm 50.00\end{array}$

TABLE 3. Basal $\mathrm{H}_{2}$, OCTT- $\mathrm{H}_{2}$ and OCTT-ACB of individuals with severe CIR

\begin{tabular}{cccccc}
\hline & $\begin{array}{c}\text { Fasting } \mathrm{H}_{2} \\
(\mathrm{ppm})\end{array}$ & $\begin{array}{c}\text { OCTT- } \mathrm{H}_{2} / 3 \\
(\mathrm{~min})\end{array}$ & $\begin{array}{c}\mathrm{OCTT}^{2} \mathrm{H}_{2} / 5 \\
(\mathrm{~min})\end{array}$ & $\begin{array}{c}\text { OCTT- } \mathrm{H}_{2} / 10 \\
(\mathrm{~min})\end{array}$ & $\begin{array}{c}\text { OCTT-ACB } \\
(\mathrm{min})\end{array}$ \\
\hline 12 & 50 & 70 & 80 & 80 \\
1.15 & 70 & 80 & 100 & 120 \\
1.66 & 30 & 70 & 70 & 120 \\
& 4.6 & 50 & 50 & 50 & 70 \\
& 5.85 & 20 & 20 & 180 & 120 \\
& 3.1 & 80 & 90 & 100 & 130 \\
& 4.1 & 70 & 80 & 100 & 80 \\
& 1.15 & 40 & 40 & 60 & 90 \\
& 1.2 & 60 & 60 & 60 & 70 \\
& 1.2 & 30 & 100 & 130 & 110 \\
& 2.45 & 50 & 50 & 70 & 110
\end{tabular}

\begin{tabular}{llllll} 
semiamplitude & $2,45 \pm 5,43$ & $50,00 \pm 30,00$ & $70,00 \pm 40,00$ & $80,00 \pm 65,00$ & $110,00 \pm 30,00$ \\
\hline
\end{tabular} 
With the purpose to explore different aspects of the results obtained, the following comparisons were carried out and statistically analyzed:

1. basal $\mathrm{H}_{2}$ between groups $\mathrm{A}, \mathrm{M}$ and $\mathrm{S}$

2. OCTT- $\mathrm{H}_{2}$ between groups $\mathrm{A}, \mathrm{M}$ and $\mathrm{S}$ and for each one of the cut off alternatives used. Thus, OCTT- $\mathrm{H}_{2} / 3, \mathrm{OCTT}-\mathrm{H}_{2} / 5$ and OCTT- $\mathrm{H}_{2} / 10$ for respectively cut off 3,5 and $10 \mathrm{ppm}$

3. OCTT-ACB between groups $\mathrm{A}, \mathrm{M}$ and $\mathrm{S}$

4. OCTT- $\mathrm{H}_{2}$ versus OCTT-ACB in groups $\mathrm{A}, \mathrm{M}$ and $\mathrm{S}$ and for each one of the cut off alternatives

The following was also submitted to statistical evaluation:

- Correlation between OCTT as measured by the $\mathrm{H}_{2}$ and ACB methods in groups $\mathrm{A}, \mathrm{M}$ and $\mathrm{S}$

The statistical analysis did not find significant differences between basal $\mathrm{H}_{2}$ values in groups $\mathrm{A}, \mathrm{M}$ and $\mathrm{S}(P>0.05)$.

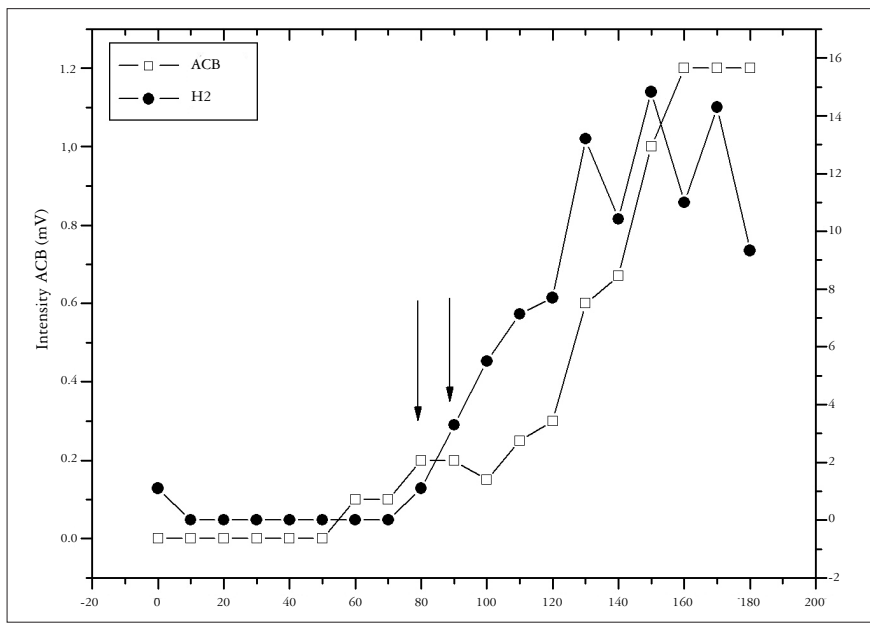

FIGURE 2. Subjects without cecoileal reflux present narrow difference between OCTT measured by $\mathrm{H}_{2}$ and ACB (see arrows)

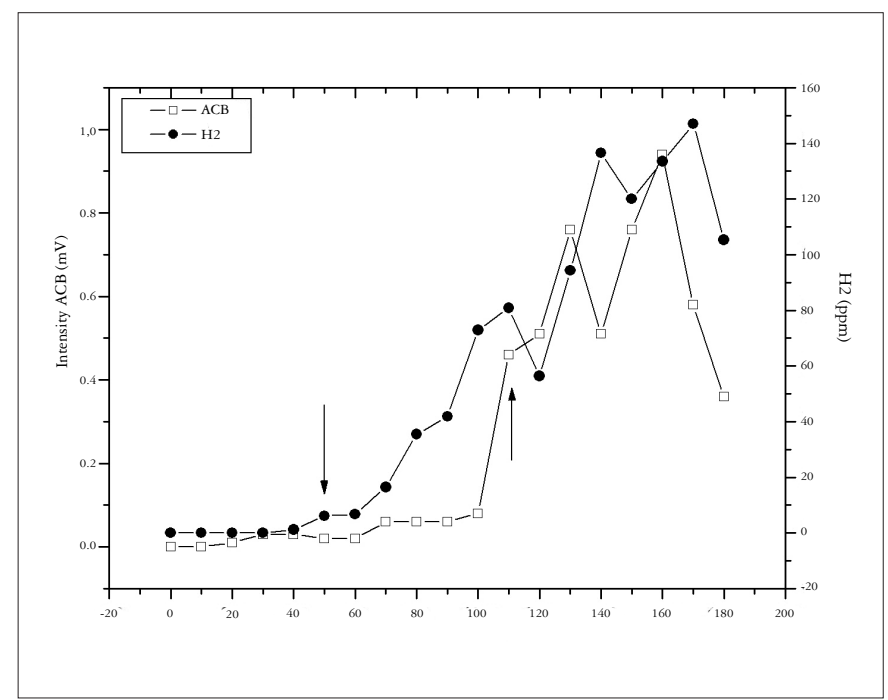

FIGURE 3. Subjects with cecoileal reflux present wide difference between OCTT measured by $\mathrm{H}_{2}$ and ACB (see arrows)
In the OCTT- $\mathrm{H}_{2}$ comparison between the groups and for each one of the cut off alternatives, no significant statistical difference was also found $(P>0.05)$, which was as well observed for OCTT by ACB $(P>0.05)$. In the comparison of OCTT as measured by both methods, OCTT- $\mathrm{H}_{2}$, in the different cut off alternatives, showed significant lower values than OCTT-ACB $(P<0.05)$, and a tendency towards a larger increase in the time intervals between them was observed in the CIR groups (Figures 2 and 3). The study on the correlation between OCTTs obtained by the two methods showed a significant association $(P<0.05)$ only in relation to group A (Figure 4) whereas it was inexistent in the others (Figures 5 and 6). These two last findings as regards shortened OCTT and the lack of correlation observed in individuals with reflux characterized a behavior that distinguishes them in relation to individuals without reflux.

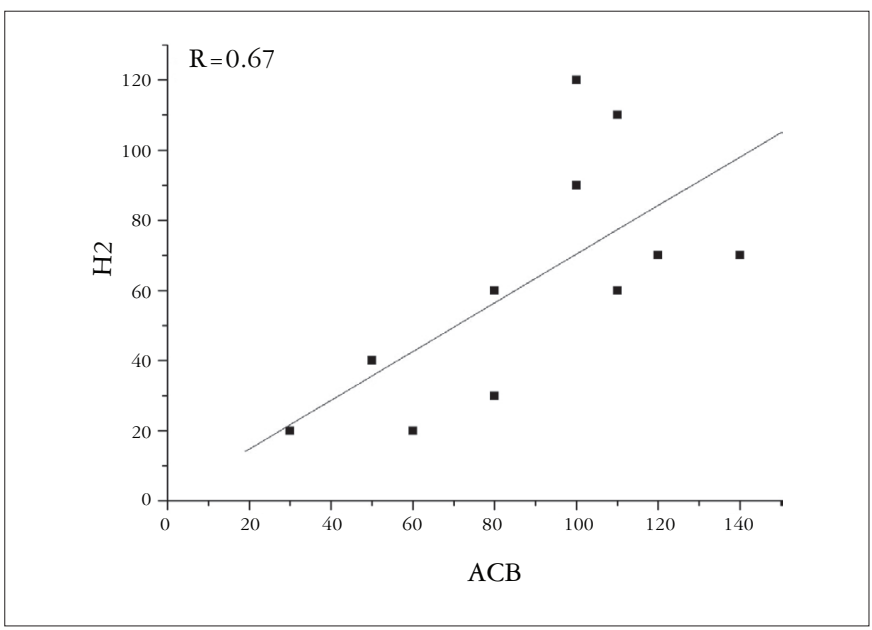

FIGURE 4. Subjects without cecoileal reflux exhibit significant $(P<0.05)$ correlation between OCTT measured by ACB and $\mathrm{H}_{2}$

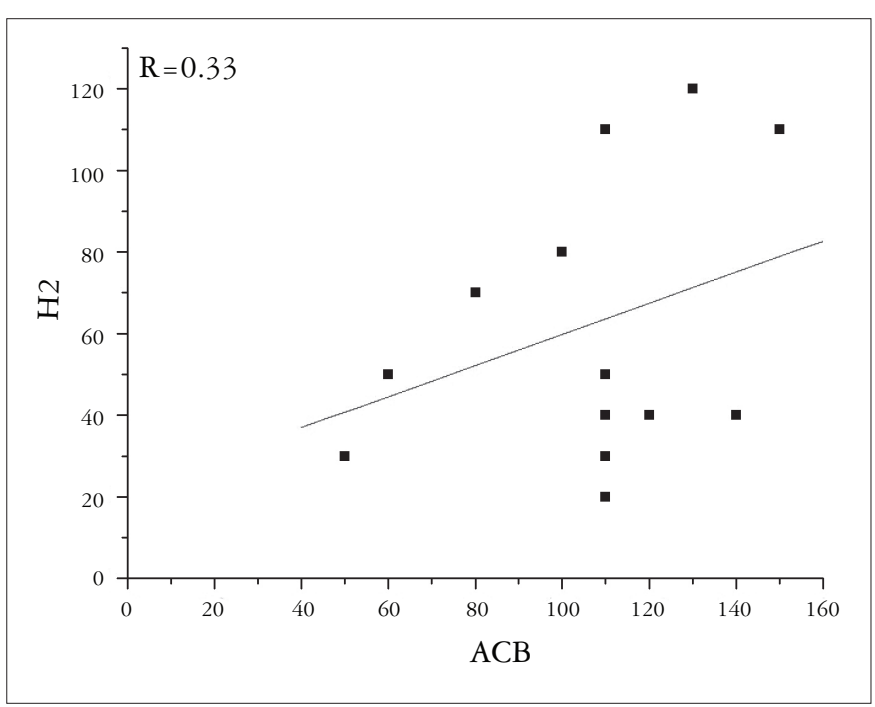

FIGURE 5. Subjects with moderate cecoileal reflux exhibit no correlation between OCTT measured by ACB and $\mathrm{H}_{2}$ 


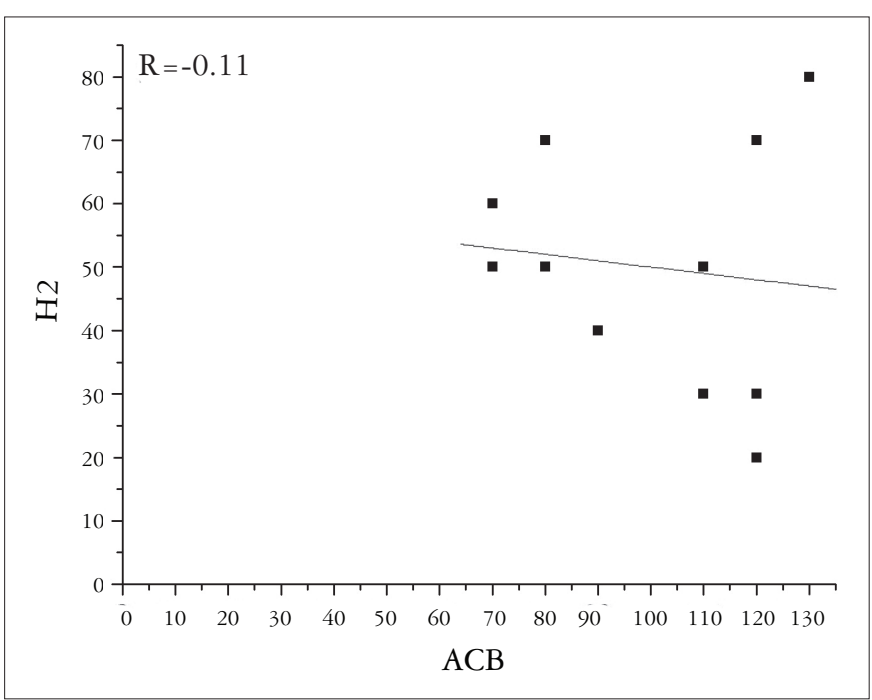

FIGURE 6. Subjects with severe cecoileal reflux exhibit no correlation between OCT'T measured by ACB and $\mathrm{H}_{2}$

\section{DISCUSSION}

Differently from gastroesophageal reflux ${ }^{(11,16)}$, the regularity of CIR in humans is unknown although it is reported in the literature $^{(7,8,10,30,33,42)}$. In a recent review of 715 barium enemas in adults ${ }^{(28)}$, CIR classified as moderate or severe was found in $25 \%$ of the exams. In the present study, we sought to explore the possibility of ileum contamination by the cecal flora in individuals with CIR.

The occurrence of ileal contamination resulting from reflux is reported in the literature as a potential condition ${ }^{(2,7,20,30,42)}$ although no specific studies have confirmed it. Existing studies show its onset in experimental models or after surgical interventions in the ileocecal valve ${ }^{(13,35,36,49)}$. As it followed a mechanism that was presumably dependent on flora ascent and not on its ingestion, the investigation on contamination by CIR required an adaptation of the method employed. In order to make this one more adequate to the study conditions, the double $\mathrm{H}_{2}$ peak-based interpretation criterion $^{(21,44,48)}$ was replaced by OCTT- $\mathrm{H}_{2}$ shortening. To test the validity of $\mathrm{OCTT}_{-} \mathrm{H}_{2}$ shortening premise, $\mathrm{ACB}$, which measures OCTT without bacterial influence, was carried out simultaneously as it was believed that, if OCTT showed to be shortened in individuals with CIR only through the $\mathrm{H}_{2}$ test, but not by $\mathrm{ACB}$, such variation could be attributed to SIBO.

In determining $\mathrm{OCTT}_{2} \mathrm{H}_{2}$, three cut off values were used based on the belief that the reflux ascending diffusion would dilute it as it moved away from ICJ, reducing the number of bacteria available to metabolize lactulose and generate $\mathrm{H}_{2}$. The reduction in $\mathrm{H}_{2}$ production could hinder its detection if only high cut off values were used.

Aiming at characterizing the ileal flora in individuals with $\mathrm{CIR}$, various aspects were analyzed. Firstly, basal $\mathrm{H}_{2}$ values were compared, which, to some authors would identify SIBO ${ }^{(41)}$. The results obtained, however, did not show significant differences between the control group and the CIR group. When $\mathrm{OCTT}_{2} \mathrm{H}_{2}$ was compared between groups A, M and S, no significant difference was also found for any of the cut off alternatives. Such findings, although contradicting the SIBO hypothesis in individuals with CIR, are surprising, particularly by taking into account more severe CIR degrees, where abundant reflux and delayed clearing function present are both strong predisposing factors to colonization of the small intestine ${ }^{(20,25)}$. Possible explanations for our results: CIR detected by radiological examination is inexistent in basal conditions; clearing impairment, suggested by barium retention, would not be reproduced in physiological conditions; the simple radiological CIR finding would not necessarily result in SIBO. Regarding the first possibility, it must be reported that, although not confirmed by specific studies, the presence of reflux shown by radiography is probably reproduced in basal conditions, since the radiological procedure is executed so as not to create excessive intraluminal pressure that may generate artifacts. Actually, during the exam, contrast is injected up to the transverse colon, from which it is conducted to the cecum by postural maneuvers, and the forced direct filling of the proximal colon is avoided. Additionally, only a minority of individuals $(25 \%)$ submitted to enema exhibit reflux, which suggests that this is a unique specific group that, differently from the rest, presents reflux not as a random event, but because they have an incontinent ICJ. Finally, experimental and clinical studies confirm the existence of reflux in basal conditions, independently of non-physiological maneuvers ${ }^{(7,10,30)}$.

The suspicion of terminal ileum clearing delay in individuals with CIR cannot be confirmed due to lack of appropriate studies. Nor is it possible to question whether such delay may be bariumspecific or extensive to other contents, due to the same reason, that is, no available publications. The literature, however, shows that emptying occurs in a complex fashion in ICJ, which is not correspondent to characteristic motor patterns, but rather a result of the integrated functions of the terminal ileum and the proximal colon that are dependent on the inhibitory and excitatory neural routes ${ }^{(9,14,18,19,38,52)}$, and involves factors such as postprandial state ${ }^{(52)}$ and food consistency ${ }^{(14)}$. In view of the pathogenic implications of inadequate clearing, as noticed in the

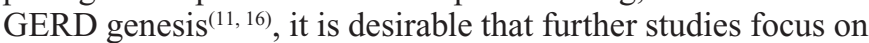
this aspect of individuals with CIR. If corroborated, the delay could favor the prolonged exposure of the ileum to germs and metabolic products originating in the colon ${ }^{(2,30,42)}$ with obvious consequences to body balance.

The presumption regarding the dissociation between CIR and ileal contamination is paradoxal since, in the former, two bacterial colonization facilitating factors are added, namely, the reflux of contaminated material and its inadequate clearing $(2,20,25,30)$. This apparent dissociation may be connected to two basic reasons: insensitivity of the detection method used and low bacterial concentration in the contaminated loop. The method's failure would result from its functioning principle, which is based on the difference in OCTT- $\mathrm{H}_{2}$ measurement between the groups. Even if those measures presented inter-group variation, it would only be statistically significant if a certain magnitude were reached, since subtle differences could be confused as identical results. Regarding bacterial concentration, 
its decrease is predictable as the refluxed content moves away from the ileocecal valve. This could determine a decrease in $\mathrm{H}_{2}$ production to non-detectable levels even if the multiplicity of the cut off values is taken into account.

Similar OCTT values by ACB ratify the hypothesis of unlikely bacterial influence on this method.

When compared, OCTT- $\mathrm{H}_{2}$ values showed to be significantly lower than those of OCTT-ACB, as described in the literature ${ }^{(40)}$. However, the fact that this difference tended to be greater in individuals with CIR called our attention once it suggested less long OCTT- $\mathrm{H}_{2}$ for the CIR group than for control. The correlation test result reinforces the latter finding by observing a significant association between the two methods only when they were compared to controls as it was inexistent in relation to individuals with CIR. OCTT- $\mathrm{H}_{2}$ shortening and the loss of correlation between the breath and ACB methods for individuals with reflux as compared to controls are compatible with the hypothesis of increased ileal flora in the former.

In conclusion, although the literature agrees in reporting damage to the barrier represented by ICJ as a cause of contamination in the small intestine, our results pointed only to indications that could corroborate such opinion. It is relevant, however, to point out that contamination demonstration models cannot be integrally compared with that in our case, since, in the latter, continence disorders were apparently functional whereas, in the former, there was structural damage to the ileocecal valve ${ }^{(12,}$ $\left.{ }^{13}, 36,49\right)$. Anyhow, the voluminous CIR found for many of the individuals in the analyzed group is impressive, which makes it difficult to admit the absence of its effects. Its mechanism, although not yet thoroughly studied, is probably associated with underlying motor alterations which compromise the fine adjustment of the complex functions of ICJ in controlling flux, adjusting sphincteric contraction, containing and clearing reflux. That the effect and reasons for CIR should be further examined and that many of the still existing questions should be resolved seem to be a relevant consideration. After all, ICJ impairment could be seriously harmful to health not only as regards the metabolic, absorptive or nutritional aspects, but also as a contributing factor in the manifestation of an intriguing digestive disorder, the irritable bowel syndrome, as a result of its motility alteration or as a factor favoring the ${ }^{(42,43)}$ entrance of bacteria in the small intestine, which, according to recent publications would trigger the symptoms of the above mentioned condition $^{(6,26,44,45,46)}$.

Machado WM, Miranda JRA, Morceli J, Padovani CR. Estudo da flora do delgado em doentes com refluxo cecoileal. Arq Gastroenterol. 2008;45(3):212-8.

RESUMO - Racional - Fato de observação não rara, é o encontro de refluxo cecoileal durante realização de enema opaco. As causas e conseqüências deste achado têm sido pouco estudadas. Objetivos - Sabendo que a junção ileocecal exerce função de barreira e proteção contra a invasão do delgado pela flora colônica, realizou-se o presente estudo com a finalidade de investigar se existe contaminação ileal em indivíduos com refluxo cecoileal ao enema opaco. Métodos - Investigaram-se 36 indivíduos, 30 mulheres e 6 homens, idade média de 54 anos, 25 com e 11 com ausência refluxo cecoileal. Todos submetidos a pesquisa de contaminação bacteriana do delgado por intermédio de teste respiratório com lactulose- $\mathrm{H}_{2}$ e a determinação do tempo de trânsito orocecal por meio de biossusceptometria de corrente alternada. A caracterização da contaminação do delgado foi baseada no encurtamento do tempo de trânsito orocecal medido pelo teste da lactulose- $\mathrm{H}_{2}$. Resultados - A comparação dos valores basais do H2, do tempo de trânsito orocecal-H ${ }_{2}$ e tempo de trânsito orocecalbiossusceptometria de corrente alternada não diferiram estatisticamente entre os grupos com e sem refluxo cecoileal. Quando comparados os tempo de trânsito orocecal- $\mathrm{H}_{2}$ e tempo de trânsito orocecal-biossusceptometria, foi observado aumento de tendência de redução do primeiro em relação ao último nos grupos com refluxo cecoileal e correlação significante entre os dois métodos apenas no grupo-controle, inexistindo nos com refluxo cecoileal. Conclusão - Encurtamento do tempo de trânsito orocecal-H $\mathrm{H}_{2}$ e sua perda de correlação com o tempo de trânsito orocecal-biossusceptometria observado em indivíduos com refluxo cecoileal, sugerem comportamento diferenciado deste grupo em relação ao grupo-controle. Possível explicação para as diferenças registradas entre os grupos, seria a presença de flora anômala nos indivíduos com refluxo cecoileal.

DESCRITORES - Refluxo cecoileal. Válvula ileocecal. Contaminação do delgado. Supercrescimento bacteriano do delgado. Junção ileocecal 


\section{REFERENCES}

1. Baffa O, Oliveira RB, Miranda JRA, Troncon LE. Analysis and development of AC biosusceptometer for orocaecal transit time measurements. Med Biol Eng Comput. 1995;33:353-7.

2. Bellón Caneiro JM, Jiménez MF, Oliveros LG. El esfíncter ileocecal en la dinámica funcional del tracto digestivo: revisión de conjunto. Rev Esp Enferm Apar Dig. 1987;72:745-8.

3. Calabuig R, Weems WA, Moody FG. Ileo-cecal junction: a valve or a sphincter? An experimental study in the opossum. Rev Esp Enferm Dig. 1996;88:828-39.

4. Camboni G, Basilisco G, Bozzani A, Bianchi PA. Repeatability of lactulose hydrogen breath test in subjects with normal or prolonged orocecal transit. Dig Dis Sci. 1988;33:1525-7.

5. Cohen S, Harris LD, Levitan R. Manometric characteristics of the human ileocecal junctional zone. Gastroenterology. 1968;54:72-5.

6. Collins SM, Barbara G. East meets West: infection, nerves, and mast cells in the irritable bowel syndrome. Gut. 2004;53:1068-9.

7. Cuche G, Malbert $\mathrm{CH}$. Relationships between cecoileal reflux and ileal motor patterns in conscious pigs. Am J Physol. 1998;274(Pt 1):g35-41.

8. Decarlo J Jr. Complications associated with diagnostic barium enema. Surgery. 1960;47:965-9.

9. Dinning PG, Bampton PA, Kennedy ML, Cook IJ. Relationship between terminal ileal pressure waves and propagating proximal colonic pressure waves. Am J Physiol. 1999;277(Pt 1):g983-92.

10. Dinning PG, Bampton PA, Kennedy ML, Kajimoto T, Lubowski DZ, Carle DJ, Cook IJ. Basal pressure patterns and reflexive motor responses in the human ileocolonic junction. Am J Physiol 1999;276(Pt 1):g331-40.

11. Dodds WJ, Dent J, Hogan WJ, Helm JF, Hauser R, Patel GK, Egide MS. Mechanism of gastroesophageal reflux in patients with reflux esophagitis. N Engl J Med. 1982;307:1547-52.

12. Fallingborg J, Pedersen $P$, Jacobsen BA. Small intestinal transit time and intraluminal $\mathrm{pH}$ in ileocecal resected patients with Crohn's disease. Dig Dis Sci. 1998;43:702-5.

13. Griffen WO Jr, Richardson JD, Medley ES. Prevention of small bowel contamination by ileocecal valve. South Med J. 1971;64:1056-8.

14. Hammer J, Camilleri M, Phillips SF, Aggarwal A, Haddad AM. Does the ileocolonic junction differentiate between solids and liquids. Gut. 1993;34:222-6.

15. Hirakawa M, Iida M, Kohrogi N, Fujishima M. Hydrogen breath test assessment of orocecal transit time: comparison with barium meal study. Am J Gastroenterol. 1988;83:1361-3

16. Holloway RH, Dent J. Pathophysiology of gastroesophageal reflux. Lower esophageal sphincter dysfunction in gastroesophageal reflux disease. Gastroenterol Clin North Am. 1990;19:517-35.

17. Jorge JMN, Habr-Gama A, Wexner SD, Ehrenpreis ED. Teste do hidrogênio expirado com lactulose como medida do tempo de trânsito orocecal(TTOC) em indivíduos normais e constipados. Rev Bras Coloproctol. 1993;13:84-90

18. Kerlin P, Phillips S. Differential transit of liquids and solid residue through the human ileum. Am J Physiol. 1983;245:g38-43.

19. Kerlin P, Zinsmeister A, Phillips S. Motor responses to food of the ileum, proximal colon, and distal colon of healthy humans. Gastroenterology. 1983;84:762-70

20. King CE, Toskes PP. Small intestine bacterial overgrowth. Gastroenterology. 1979;76(Pt 1):1035-55.

21. King CE, Toskes PP. Comparison of the 1-gram ${ }^{14} \mathrm{C}$ xylose, 10 -gram lactulose- $\mathrm{H}_{2}$, and 80 -gram glucose- $\mathrm{H}_{2}$ breath tests in patients with small intestine bacterial overgrowth. Gastroenterology. 1986;91:1447-51

22. Kruis W, Phillips SF, Zinsmeister A. Flow across the canine ileocolonic junction role of the ileocolonic sphincter. Am J Physiol. 1987;252:g13-8.

23. Kumar D, Phiillips SF. The contribution of external ligamentous attachments to function of the ileocecal junction. Dis Colon Rectum. 1987;30:410-6.

24. Kumar D, Phillips SF, Brown ML. Reflux from ileum to colon in the dog. Role of external ligamentous attachments. Dig Dis Sci. 1988;33:345-52.

25. Li E. Bacterial overgrowth. In: Yamada T, editor. Textbook of gastroenterology. 3rd ed. Philadelphia: Lippincott Williams \& Wilkins; 1999. p.1697-703.

26. Lin HC. Small intestinal bacterial overgrowth - a framework for understanding irritable bowel syndrome. JAMA. 2004;292:852-8.
27. Machado WM. Flora do delgado em megas chagásicos: estudo pelo teste do $\mathrm{H}_{2}$ respiratório. Arq Gastroenterol. 1995;32:19-23.

28. Machado WM, Morceli J. Prevalência, classificação e características do refluxo cecoileal diagnosticado pelo enema opaco. Radiol Bras. 2006;39:107-11.

29. Maffei HVL, Daher SR, Moreira FL. Carbohydrate malabsorption in infants with diarrhea: diagnostic and evolutive aspects. Arq Gastroenterol. 1984;21:136-42.

30. Malbert CH. The ileocolonic sphincter. Neurogastroenterol Motil. 2005;17(Suppl 1): 41-9.

31. Metz G, Gassull MA, Drasar BS, Jenkins DJ, Blendis L. Breath-hydrogen test for small-intestinal bacterial colonisation. Lancet. 1976;1:668-9.

32. Metz G, Gassull MA, Leeds AR, Blendis LM, Jenkins DJA. A simple method of measuring breath hydrogen in carbohydrate malabsortion by end-expiratory sampling. Clin Sci Mol Med. 1976;50:237-40.

33. Miller RE. Complete reflux small bowel examination. Radiology. 1965;84:457-63.

34. Miranda JR, Oliveira RB, Sousa PL, Braga FJ, Baffa O. A novel biomagnetic method to study gastric antral contractions. Phys Med Biol. 1997;42:1791-9.

35. Monereo J, Martinez-Almoyna C. Incompetencia de la válvula ileocecal. Rev Esp Enferm Apar Dig. 1977;49:467-84.

36. Myrvold H, Tindel MS, Isenberg HD, Stein TA, Scherer J, Wise L. The nipple valve as a sphincter substitute for the ileocecal valve: prevention of bacterial overgrowth in the small bowel. Surgery. 1984;96:42-7.

37. Nasmyth DG, Williams NS. Pressure characteristics of the human ileocecal region- a key to its function. Gastroenterology. 1985;89:345-51.

38. Neri M, Phillips SF, Fich A, Haddad AC. Canine ileocolonic sphincter: flow, transit, and motility before and after sphincterotomy. Am J Physiol. 1991;260(Pt 1):g284-9.

39. Norman GR, Streiner DL. Biostatistics. The bare essentials. St Louis: Mosby; 1994.

40. Oliveira RB, Baffa O, Troncon LE, Miranda JR, Cambrea CR. Evaluation of a biomagnetic technique for measurement of orocaecal transit time. Eur J Gastroenterol Hepatol. 1996;8:491-5.

41. Perman JA, Modler S, Barr RG, Rosenthal P. Fasting breath hydrogen concentration: normal values and clinical application. Gastroenterology. 1984;87:1358-63.

42. Phillips SF, Quigley EM, Kumar D, Kamath PS. Motility of the ileocolonic junction. Gut. 1988;29:390-406.

43. Phillips SF, Camilleri M. The ileocecal area and the irritable bowel syndrome Gastroenterol Clin North Am. 1991;20:297-311.

44. Pimentel M, Chow EJ, Lin HC. Eradication of small intestinal bacterial overgrowth reduces symptoms of irritable bowel syndrome. Am J Gastroenterol. 2000;95:3503-6.

45. Pimentel M, Soffer EE, Chow EJ, Kong Y, Lin HC. Lower frequency of MMC is found in IBS subjects with abnormal lactulose breath test, suggesting bacteria overgrowth. Dig Dis Sci. 2002;47:2639-43.

46. Pimentel M, Chow EJ, Lin HL. Normalization of lactulose breath testing correlates with symptom improvement in irritable bowel syndrome: a double-blind, randomized, placebo-controlled study. Am J Gastroenterol. 2003;98:412-9.

47. Read NW, Al-Janabi MN, Bates TE, Holgate AM, Cann PA, Kinsman RI, McFarlane A, Brown C. Interpretation of breath hydrogen profile obtained after ingesting a solid meal containing unabsorbable carbohydrate. Gut. 1985;26:834-42.

48. Rhodes JM, Middleton P, Jewell DP. The lactulose hydrogen breath test as a diagnostic test for small bowel bacterial overgrowth. Scand J Gastroenterol. 1979;14:333-6.

49. Richardson JD, Griffen WO Jr. Ileocecal valve substitutes as bacteriologic barriers. Am J Surg. 1972;123:149-53

50. Singleton AO Jr, Redmond DC 2nd, McMurray JE. Ileo-cecal resection and small bowel transit and absorption. Ann Surg. 1964;159:690-4.

51. Solomons NW, Viteri FE, Hamilton LH. Application of a simple gas chromatographic technique for measuring breath hydrogen. J Lab Clin Med. 1977;90:856-62.

52. Spiller RC, Brown ML, Phillips SF. Emptying of the terminal ileum in intact humans - influence of meal residue and ileal motility. Gastroenterology. 1987;92:724-9.

53. Strocchi A, Corazza G, Ellis CJ, Gasbarrini G, Levitt MD. Detection of malabsorption of low doses of carbohydrate: accuracy of various breath $\mathrm{H}_{2}$ criteria. Gastroenterology. 1993; $105: 1404-10$

54. Weisbrodt NW. Motility of the small intestine. In: Johnson LB, editor. Physiology of the gastrointestinal tract. 2nd ed. New York: Raven Press; 1987. p.631-64.

Recebido em 3/9/2007. Aprovado em 9/10/2007. 